\title{
U-Pb dating of TSR calcite in the Lower Cambrian in the western Tarim Basin
}

TAO XIAOWAN ${ }^{1 *}$, LI JIANZHONG ${ }^{1}$, CAI CHUNFANG ${ }^{2}$, HU ANPING $^{3}$, YANG HANXUAN ${ }^{3}$, HUANG YAHAO ${ }^{4}$, CHEN YANYAN $^{1}$

${ }^{1}$ Research Institute of Petroleum Exploration \& Development, PetroChina, Beijing 100083, China

(*correspondence: taoxiaowan@petrochina.com.cn)

2 Institute of Geology and Geophysics, Chinese Academy of Sciences, Beijing 100029, China

${ }^{3}$ PetroChina Hangzhou Research Institute of Geology, Hangzhou 310023, China

${ }^{4}$ Yangtze University, Wuhan 430100, China

Although thermochemical sulfate reduction (TSR) has been extensively investigated from case studies and experimental simulation, no TSR has been dated so far except unprecise estimation from fluid inclusions and burial history. A case from the Lower Cambrian dolostones in Well Qiaotan 1, Buchu uplift, is investigated to time TSR. Many sulfur-bearing species including element sulphur, pyrite, pyrobitumen, gypsum and barite are found in the dolostones to co-grow with quartz and calcite. High $\mathrm{H}_{2} \mathrm{~S}$ content $(8 \%)$ in fluid incluions from quartz with homogenization temperatures from 140 to $180^{\circ} \mathrm{C}$, and element sulfur with sulfur isotopic compostion from $24 \%$ to $25 \% 0$ close to the gypsum from $32 \% 035 \%$ and the coeval seawater, suggest that these reduced sulfur species may have a sufur contribution from thermochemical sulfate reduction, although pyrite with $\delta^{34} \mathrm{~S}$ values from $-26 \%$ to $-30 \%$ may have an origin of bacterial sulfate reduction. Thus, the associated calcite with homogenization temperatures from 140 to $180^{\circ} \mathrm{C}$ must have a origin of TSR. The calcite was measured using $\mathrm{U}-\mathrm{Pb}$ dating to give an age of $220 \pm 30 \mathrm{Ma}$, indicating the TSR may have occurred during this period. 